\title{
A “FRAUDE DA LOCADORA” E SUAS IMPLICAÇÕES NO DIREITO PENAL
}

\author{
THE “FRAUDE DA LOCADORA” AND THE \\ IMPLICANTIONS IN CRIMINAL LAW
}

*Acadêmica do curso de Direito da Universidade Estadual do Mato Grosso do Sul (UEMS).

E-mail:

michelekuchar@gmail.com

***Doutoranda em Direito pela Instituição Toledo de Ensino (ITE). Mestre em Fronteiras e Direitos Humanos (UFGD). Docente no curso de Direito da Universidade Estadual de Mato Grosso do Sul (UEMS).

E-mail:

karine.cordazzo@hotmail.com

\section{Michele Kuchar Matte* Karine Cordazzo**}

Como citar: MATTE, Michele Kuchar; CORDAZZO, Karine. A 'fraude da locadora” e suas implicações no Direito Penal. Revista do Instituto de Direito Constitucional e Cidadania - IDCC, Londrina, v. 5, n. 2, e001, ago/dez, 2020. ISSN: 2596-0075. DOI: 10.48159/revistadoidcc.v5n2.matte.cordazzo

Resumo: Este trabalho apresenta uma análise sobre a prática criminosa conhecida popularmente como "fraude da locadora", ela consiste em um cliente alugar um carro de locadoras de veículos, para, a princípio, o utilizar e logo após tal veículo é dado como roubado, sendo comunicado tanto a locadora quanto a autoridade policial e não há devolução do bem. No entanto, o carro é utilizado para outros fins não legais. Assim, há dificuldades de caracterizar-se o crime, pois há muitas similaridades nos delitos de furto mediante fraude, estelionato e apropriação indébita. Foi utilizado a pesquisa bibliográfica e o estudo de julgados para a diferenciação, após análise mais aprofundada vê-se que o crime de furto mediante fraude é menos confundido. Nos outros dois crimes, há ainda muita discricionariedade do julgador. Conclui-se que tal discussão vem para facilitar o melhor direcionamento do crime imputado ao réu.

Palavras-chave: Estelionato; apropriação indébita; furto mediante fraude.

Abstract: This work presents an analysis of the criminal practice popularly known as "fraude da locadora", it consists of a customer renting a car from car rental companies, in principle, to use it and after such vehicle is reported as stolen, being reported both the rental company and the police authority and there is no return of the car. However, the car is used for other non-legal purposes. Thus, there are difficulties in characterizing the crime, as there are many similarities in the crimes of theft through fraud, swindle and embezzlement. Bibliographic research and the study of precedente were used for differentiation, it appears that the crime of theft through fraud is less confused. In the other two crimes, there is still a lot of discretion by the judge. It is concluded that such discussion comes to facilitate the better targeting of the crime attributed to the defendant.

Keywords: Swindle; embezzlement; theft through fraud. 


\section{INTRODUÇÃO}

Há grandes dificuldades na classificação de determinadas práticas criminosas, afinal, em determinadas condutas pode haver nuances que geram dúvidas quanto a sua correta catalogação. Por exemplo, em casos que um cliente aluga um carro de locadora de veículo, para, a princípio, fazer uma viagem e logo após tal veículo é dado como roubado, sendo comunicado tanto a locadora quanto a autoridade policial. No entanto, não há provas firmes de que houve realmente o roubo e há indícios de que o bem foi utilizado para fins diversos, inclusive ilegais, como o tráfico de drogas, ou para a revenda.

Manchetes relacionados a golpes de carros alugados no Brasil se tornou tornaram algo corriqueiro. Por exemplo, no site do G1 Santa Catarina "Criminosos aplicam golpes contra locadoras de veículos e furtam carros em Santa Catarina” (ROCKENBACH,2019). Ademais, no Jornal Diário Corumbaense "PRF apreende em 24h, segundo carro locado em outro Estado que seguia para a Bolívia” (NUNES, 2019).

Em uma das situações o crime foi imputado como apropriação indébita. Já em outra, é caracterizado como estelionato, demonstrando a inconstância na identificação dessa prática criminosa. Ademais, tal golpe, caso haja vigilância da vítima, pode ser considerado furto mediante fraude.

Com a investigação criminal percebe-se a prática delituosa de falsa comunicação de crime à autoridade policial. Entretanto, questiona-se se tal crime pode ser classificado como estelionato, furto mediante fraude ou apropriação indébita. Tal discussão é a que será discorrida neste artigo, sendo isso feito pelos entendimentos de doutrinas e da jurisprudência em voga no Brasil, através de pesquisa exploratória e bibliográfica com levantamento de dados encontrados na literatura, em área do Direito, com leitura sistemática a fim de dar fundamento teórico ao estudo.

\section{DA PRÁTICA DO ESTELIONATO}

Segundo o tipo penal, estabelecido no Código Penal Brasileiro, estelionato se caracteriza por:

Art. 171 - Obter, para si ou para outrem, vantagem ilícita, em prejuízo alheio, induzindo ou mantendo alguém em erro, mediante artifício, ardil, ou qualquer outro meio fraudulento:

$\S 2^{\circ}$ - Nas mesmas penas incorre quem: 
Disposição de coisa alheia como própria

I - vende, permuta, dá em pagamento, em locação ou em garantia coisa alheia como própria;

Neste artigo será tratada a prática do estelionato presente no art. 171, §2 , inciso I, sendo incorre nesse artigo, quem pratica a disposição de coisa alheia como própria.

Segundo Rogério Sanches Cunha (2017, p. 363) a explicação do estelionato se desenvolve, pois:

Pune-se aquele que, por meio da "astúcia", "da esperteza", do "engodo", da "mentira", procura despojar a vítima do seu patrimônio fazendo com que esta entregue a coisa visada espontaneamente, evitando, assim, retirá-lo por meios violentos. Em suma, o agente busca lesar a vítima em seu patrimônio, de maneira sutil, mas sempre segura.

A fraude, nesse contexto, pode ser empregada para induzir ou manter a vítima em erro. No ato de induzir é o agente quem cria na vítima a falsa percepção da realidade. A forma de obter-se a vantagem é por meio do “expediente fraudulento”, desde que idôneo para lesar o bem jurídico. (CUNHA, 2017, p. 364)

O dispositivo desenvolve os meios fraudulentos, sendo qualquer ação ou omissão humana opta a enganar outrem. O tipo subjetivo do crime se caracteriza pelo dolo de executar, tal fato é possível de ser observado no caso concreto quando aluga o carro de Empresa na intenção de desfazer-se do objeto.

É importante observar a especificação da disposição de coisa alheia como própria, relativo ao caso analisado, a doutrina desenvolve seu significado, Rogério Sanches Cunha estabelece que o punido é o agente que vende (transferência da coisa mediante pagamento), permuta (troca), dá em pagamento (entrega, com o consentimento do credor, de determinada coisa como pagamento por prestação eventualmente devida), locação (o agente cede a coisa, mediante remuneração, por tempo determinado ou não), dação em garantia (penhor, anticrese e hipoteca), coisa alheia como própria. (CUNHA, 2017, p. 368)

Para Souza e Japiassú (2018, p. 767) o Estelionato é crime material que se consuma com o proveito patrimonial (a vantagem econômica ilícita) e com o prejuízo alheio. Nesse sentido: "O delito de estelionato consuma-se com a obtenção de vantagem ilícita em prejuízo alheio, desde que o agente desfrute, durante algum tempo desta vantagem, não desaparecendo o crime pelo ressarcimento do dano.” 
Ademais, a disposição de coisa alheia como própria é estabelecido no artigo 171, I do Código Penal como “vende, permuta, dá em pagamento, em locação ou em garantia coisa alheia como própria”, realidade que é a ocorrida no caso narrado.

Mesmo que, a priori, o contrato de aluguel firmado com a empresa seja lícito, há o dolo anterior ao meio do emprego fraudulento, demonstrando a intenção, já ao locar o carro de se desfazer do bem.

Na Fraude para recebimento de indenização ou valor de seguro, estabelecido como crime de estelionato, a prática tem fins parecidos, tendo a vantagem própria, com obtenção geralmente de dinheiro com a indenização do seguro, somado ao valor da venda ou perda do objeto previamente adquirido. Tal ação criminosa é caracterizada no artigo 171, V, do Código Penal, isso mostra que há semelhanças, mas o modus operandi são diferentes.

Tratando-se de fraude para recebimento de indenização ou valor de seguro, o sujeito ativo será o segurado, e, dessa forma, o passivo será a seguradora.

Note-se que se o agente destrói a coisa ou pratica a lesão sem o conhecimento do segurado, com o intuito de se beneficiar da indenização a ser recebida, este responderá pelo estelionato, porém na forma do caput, em concurso com o dano ou com a lesão corporal.

Analogicamente com artigo 171, V, o agente pode destruir ou ocultar coisa própria e lesar ou agravar lesão no próprio corpo, no intuito de obter indenização securitária, mas o contrato obriga as partes e deve ser vigente e válido à época do emprego da fraude. Assim, caso o contrato não seja vigente, o estelionato não se consumará, podendo ocorrer a tentativa. (SOUZA; JAPIASSÚ, 2018, p.770)

Observa-se que o contrato lícito é algo essencial para o estelionato e para a indenização decorrida da fraude. Já no estelionato relacionado ao golpe do aluguel de carro, existe, em alguns casos, emprego de documentos falsos o que impediria a licitude do contrato, mas não o estelionato ou supostamente a apropriação indébita.

\section{DA APROPRIAÇÃO INDÉBITA}

O crime de apropriação indébita, segundo parágrafo 168 do Código Penal Brasileiro, se caracteriza por: “Art. 168 - Apropriar-se de coisa alheia móvel, de que tem a posse ou a detenção: Pena - reclusão, de um a quatro anos, e multa.” 
Segundo Rogério Sanches Cunha (2017, p. 341), o bem jurídico tutelado é, a exemplo dos demais delitos contra o patrimônio, a propriedade. O agente, abusando da condição de possuidor ou detentor, passa a ser o bem móvel como seu, dele arbitrariamente se apropriando.

Nos termos do art. 1.196 do Código Civil Brasileiro, "Considera-se possuidor todo aquele que tem de fato o exercício, pleno ou não, de algum dos poderes inerentes à propriedade".

O art. 1.198, por sua vez, dispõe: "Considera-se detentor aquele que, achando-se em relação de dependência para com outro, conserva a posse em nome deste e em cumprimento de ordens ou instruções suas". Assim, o infrator do tipo penal, se apropria de objetos de outras pessoas como se seu fosse, conservando a posse do bem e o vendendo para obter vantagem indevida ou para uso próprio.

A consumação ocorre quando o agente transforma a posse ou detenção que exerce sobre o bem em domínio. Para isso, ele pratica atos inerentes à qualidade de dono, incompatíveis com a possibilidade de ulterior restituição da coisa, um exemplo é a venda do carro, sendo este o momento que ocorre a mudança da posse do objeto. (CUNHA, 2017, p. 345)

Já em relação à consumação do crime, conforme se pode perceber, é de difícil precisão. Em regra, só se evidencia quando há a real recusa de devolução ou é evidente a consumação da lesão. Contudo, na prática, a tentativa é sempre de difícil ocorrência. (SOUZA; JAPIASSÚ, 2018, p. 757)

Em relação ao tipo subjetivo, este é composto do dolo, a vontade de praticar é posterior à apropriação e ao recebimento de boa-fé, regular e legítimo da coisa. Entende-se que o animus domini encontra-se ínsito ao dolo geral. Contudo, alguns consideram necessário o elemento subjetivo, consistente na vontade de ter a coisa para si (animus rem sibi habendi). Seria, assim, a "malícia” que sobrevém à posse lícita da res. Nesse sentido, Regis Prado entende ser necessário não só o dolo, mas o especial fim de obter para si ou para outrem um proveito, tornando-se indiferente se o proveito foi ou não conseguido. (SOUZA JAPIASSÚ, 2018, apud PRADO, 2017 p. 306)

Desse modo, a apropriação indébita precisa de um dolo de ser dono do objeto e, assim, praticar ações como a venda do bem. Para maior esclarecimento, o subjetivismo do animus domini é relacionado a vontade do sujeito de ter o bem para si, após ter o objeto de sua posse, teoricamente, ele pode praticar qualquer ação com ele, inclusive, vender. Por isso, a inversão do ânimo da posse ocorre com a efetivação da venda do bem, no caso concreto. 


\title{
3. Do FURTO MEDIANTE FRAUDE
}

Segundo o Código Penal Brasileiro no artigo 155, §4 II, furto mediante fraude se caracteriza por:

\author{
Furto \\ Art. 155 - Subtrair, para si ou para outrem, coisa alheia móvel: \\ Pena - reclusão, de um a quatro anos, e multa. \\ Furto qualificado \\ $\S 4^{\circ}$ - A pena é de reclusão de dois a oito anos, e multa, se o crime é cometido: \\ II - com abuso de confiança, ou mediante fraude, escalada ou destreza;
}

Subtrair, significa tirar, fazer desaparecer ou retirar. É necessário obter o ânimo fundamental, componente da conduta de furtar. Já coisa é tudo aquilo que existe, podendo tratar-se de objetos inanimados ou de semoventes. É necessário que a coisa tenha, para seu dono ou possuidor, algum valor econômico. Em furto, se encaixa apenas os móveis, tratando-se de sentido real, e não jurídico. (NUCCI, 2020, p. 989)

Segundo Cleber Masson (2014, p. 392), ao desenvolver o conceito de fraude somado ao furto:

Fraude é um artifício ou ardil, o meio enganoso utilizado pelo agente para diminuir a vigilância da vítima ou de terceiro sobre um bem móvel, permitindo ou facilitando sua subtração. (...) A fraude, qualificadora do furto, há de ser empregada antes ou durante a subtração (antecede a consumação do furto) exigi-se seja utilizada pelo agente para iludir a vigilância ou atenção da vítima ou de terceiro sobre o bem. A fraude posterior à consumação do crime não qualifica o crime também não se confunde com estelionato - a fraude, funciona como qualificadora se presta a diminuir a vigilância da vítima sobre o bem, permitindo ou facilitando a subtração; no estelionato é elementar e se destina a colocar a vítima (ou terceiro) em erro, mediante uma falsa percepção da realidade, fazendo com que ela espontaneamente lhe entregue o bem. Não há subtração, a fraude antecede o apossamento da coisa e é causa para ludibriar sua entrega pela vítima.

É possível analisar, desse modo, que no furto mediante fraude é preciso a vontade de furtar e a vítima deve estar vigilante em relação ao bem, isso significa que ela não entrega o bem por sua vontade e sim ele é subtraído. Diferente das outras abordagens como o estelionato e a apropriação indébita.

\section{DISTINÇÃO DOGMÁTICA ENTRE ESTELIONATO, FURTO MEDIANTE FRAUDE E APROPRIAÇÃO INDÉBITA}

O furto mediante fraude utiliza-se de artifício fraudulento para burlar a vigilância da vítima. Assim, ocorre a subtração após ludibriar a vigilância dela, pois o objeto sempre tem 
posse vigiada, ainda que mitigadamente. Dessa forma, por exemplo, o sujeito que se apresenta como comprador de automóvel, recebe-o para dar uma volta, e não o devolve, pratica o crime de furto mediante fraude. (SOUZA; JAPIASSÚ, 2018, p. 731)

Ademais, caso o agente receba a coisa já com a intenção de não a devolver em um atendimento, por exemplo, e se o funcionário se aproveita de momento de distração do patrão para se apropriar do objeto há a ocorrência de furto mediante fraude. (CUNHA, 2017, p. 343)

Em contraponto, o Estelionato utiliza-se do artifício fraudulento com o objetivo de obter o consentimento da vítima, a direcionando a cometer erro, tendo assim a posse permitida do objeto. A má-fé existe desde o início da conduta, sendo todas as ações praticadas para obter o consentimento da vítima para a obtenção da vantagem ilícita. (SOUZA, JAPIASSÚ, 2018, p. 768).

Desse modo, aquele que entrega cheque falsificado para a compra de automóvel, recebendo não só o veículo, como também o recibo da compra, pratica o crime de estelionato. (NUCCI, 2020, p. 1075). Um exemplo dado por Cunha (2017, p. 344) é a utilização um contrato de locação para artifício de enganar, praticando o estelionato.

Apropriação indébita é a mais desenvolvida em explicação para não ser confundida com outros crimes, Souza e Japiassú (2018, p. 768) narram que não há má fé ab initio, mas aquilo que se denomina "dolo subsequente”, ou seja, a "malícia” do agente que sobrevém à posse de boa-fé.

Os principais requisitos da apropriação indébita são relacionados à entrega voluntária do bem pela vítima, seja com sua concordância expressa ou tácita. A posse e a detenção devem ser desvigiadas, permitindo a apropriação. Ademais, a ação deve recair sobre coisa alheia móvel, não incluindo bens imóveis à tipicidade do crime.

Há a observação da inversão do ânimo da posse, pois após obter legitimamente a coisa, o agente passa a agir como se fosse seu dono. Apura-se a inversão por meio de atos de disposição, como venda e locação, ou pela recusa mesma em restituir a coisa. Na apropriação indébita, não há má-fé $a b$ initio, mas aquilo que se denomina como “dolo subsequente”, ou seja, a “malícia” do agente sobrevém à posse de boa-fé.

A distinção de estelionato e apropriação indébita para Cleber Masson (2014, p. 545) é a do momento que desponta o dolo de locupletar-se perante o patrimônio alheio, na apropriação indébita o dolo é sucessivo, enquanto no estelionato o dolo é antecedente e $a b$ initio.

Dessa forma, segundo Souza e Japiassú (2018, p. 768) o estelionato e o furto mediante fraude são modalidades delituosas parecidas que nem sempre é possível uma classificação sem 
controvérsias. No primeiro crime, verifica-se que a vítima se despoja do bem em decorrência do artifício fraudulento engendrado pelo réu, já em relação ao furto mediante fraude, essa é apenas um meio para diminuir a vigilância do ofendido, para ocorrer a efetiva subtração

Segundo Cleber Masson (2014, p. 394), o crime envolvendo test drive de veículos automotores caracteriza estelionato, mas a jurisprudência consolidou o entendimento de que se trata de furto qualificado pela fraude, fundamentando-se na precariedade da posse e, principalmente, em motivos de política criminal. Dessa forma, busca-se a reparação da vítima relativamente à reparação do dano, uma vez que os contratos de seguro são obrigados ao ressarcimento de crimes de furto, mas estão isentos na hipótese de estelionato. Isso demonstra que os interesses da política criminal atuante ajudam a definir certas controvérsias, em alguns casos.

Atualmente, o crime tipificado como apropriação indébita é a temática de um projeto de lei do Senhor Juninho do Pneu, o objetivo é de tipificar e aumentar as penas para os crimes de apropriação indébita de veículos locados de locadoras ou outrem. A redação, caso aprovada, será a seguinte: Art.168-B. Apropriar-se de veículo automotivo locado, com intuito de uso próprio; comercialização e/ou repasse a terceiros: Pena - reclusão, de seis a quinze anos, e multa.

A justificativa utilizada pelo deputado é a de que falsos clientes alugam carros em locadoras, não os devolvendo e, muitas vezes, os utilizando para praticar outros crimes. Segundo o narrado, a jurisprudência entende que incorre nas penas do art. 168, “caput”, do Código Penal, aquele que não devolve o automóvel alugado à locadora após o decurso do prazo fixado no contrato de locação.

Para a averiguação de sua constitucionalidade, o projeto de lei foi estudado pela comissão de constituição e justiça e de cidadania, neste momento já sendo o projeto de lei n. 2.725, de 2019. No que vale à juridicidade, o relator alega que as balizas penais foram muito elevadas, destoando do arcabouço normativo existente.

Ato contínuo, o relator alega que esse modus operandi, na maior parte das vezes, amolda-se, na realidade, ao crime de estelionato, presente no artigo 171, do Código Penal. No entanto, frequentemente não se consegue apurar a existência da fraude no momento da locação, o que afastaria a configuração do estelionato, subsistindo a possibilidade de punição do infrator pela prática da apropriação indébita. 
Destarte, é designada como mais adequada a inclusão de formas qualificadas nos delitos de apropriação indébita e de estelionato. Dessa forma, o relator produziu o apensado PL n. 4.017/2019.

O crime de apropriação indébita, terá a qualificadora estabelecida desse modo, observe:

Art. 168.

Apropriação indébita na locação de veículo automotor

$\S 1^{\circ}$ Se o crime é cometido mediante locação de veículo automotor, a pena é de reclusão, de dois a sete anos, e multa.

Aumento de pena

$\S 2^{\circ}$-A pena é aumentada de um terço, quando o agente recebeu a coisa:

I -em depósito necessário;

II-na qualidade de tutor, curador, síndico, liquidatário, inventariante, testamenteiro ou depositário judicial;

III - em razão de ofício, emprego ou profissão. (NR)

Já no crime de estelionato o projeto de lei preleciona ao artigo 171, assim, analise:

Art. 171.

Estelionato na locação de veículo automotor

$\S 5^{\circ}$ Se o crime é cometido mediante locação de veículo automotor, a pena é de reclusão, de dois a oito anos, e multa. (NR)

Desse modo, tal projeto de lei está em trâmite no Congresso Nacional para sua aprovação, se aprovado, tornará mais seguro para as locadoras. Outro ponto importante, ele dificultará o fluxo de veículos no Brasil que participaram do golpe, que não são classificados nos sistemas de segurança brasileiros, tal demanda dificulta a posterior utilização para outras práticas criminosas.

\section{DA INTERPRETAÇÃO DOS TRIBUNAIS SOBRE OS DELITOS}

As decisões dos Tribunais, para o direito brasileiro, são essenciais para a resolução de dúvidas jurídicas, dessa forma, é importante sua análise.

É possível observar na interpretação do Tribunal de Justiça do Paraná que o que ludibria a boa-fé da vítima, locando veículo com documentos falsos e não o devolvendo ao termo do contrato pratica furto mediante fraude e isso impõe a indenização pelo dano experimentado. (PR Apelação Cível - 0214135-1, Relator: Prestes Mattar, Data de Julgamento: 12/11/2002)

Ademais, analisa-se pelo Superior Tribunal de Justiça, o Habeas Corpus n 560.437-SE (2020/0028313-0), a locação de veículo para terceiros e não devolução no prazo préestabelecido se caracteriza apropriação indébita. Analise o trecho: 
[...] Ao proferir sentença condenatória no feito, o togado sentenciante asseverou que, "de acordo com o depoimento do empresário Jeã Gomes (proprietário da empresa de aluguel de veículos), o aludido carro foi alugado para uma terceira pessoa, a qual, passado o período de aluguel, sumiu sem a devida devolução", estando "demonstrada a materialidade delitiva", ao passo que "a autoria, de igual banda, também está evidenciada nos autos", pois "os réus afirmaram ter ciência da situação do veículo, o qual foi locado por uma terceira pessoa, de nome MAURÍCIO", sendo que, "mesmo cientes do encerramento do prazo de aluguel, não devolveram o automóvel" (e-STJ fl. 623). [...] Por sua vez, a Corte de origem sublinhou que "apesar dos Apelantes não terem confessado a prática delituosa, restou devidamente comprovado que o veículo gol, placa PKH 0040 foi locado por terceira pessoa e não devolvido dentro do prazo contratado, estando na posse dos acusados que sabiam que já havia passado o prazo para devolução" (e-STJ fl. 830). [...] Consignou que, "conforme depoimento do representante da empresa LOK, Jeâ Gomes, foi feito um boletim de ocorrência e o veículo foi localizado em Sergipe, estando, desta forma, devidamente demonstrado o dolo especifico dos réus de ter a coisa como se donos fossem" (e-STJ fl. 830). (HC 560.437/SE, Rel. Ministro Jorge Mussi, julgado em 12/02/2020, publicado em 13/02/2020). (Grifo nosso)

Neste conflito de competência $n^{\circ}$ 163.464-DF (2019/0025129-3), os dois juízos necessitavam a melhor caracterização da prática criminosa, sendo ela estelionato ou apropriação indébita. Assim, é possível compreender que:

O representante da locadora informou, na mesma ocasião, que o veículo de placa PXY-5171 teve, fraudulentamente, transferida a sua propriedade para a pessoa de José de Assis Araújo, na cidade de Altamira/PA, cf. doc. à e-STJ fl. 34.

1. É pressuposto do crime de apropriação indébita a anterior posse lícita da coisa alheia, da qual o agente se apropria indevidamente.

2. Não possuindo o preposto de empresa autorização para receber os pagamentos de que se apropriou indevidamente, afastada está a elementar do delito de apropriação indébita referente à posse lícita [...].

(Conflito de Competência 165.404, Rel. Ministro Nefi Corneiro, julgado em 17/09/2019, publicado em 18/09/2019). (Grifo nosso)

Analisando a decisão Superior Tribunal de Justiça, é possível caracterizar que em casos de tentativa de vendas de veículos previamente locados, há o crime de estelionato, pela obtenção de vantagem ilícita pelo réu. (Habeas Corpus n 548.435 - SE Relator: Ministro Reynaldo Soares Da Fonseca. Julgado em 29/09/2019. Data de publicação 02/12/2019.)

Em decisão do Superior Tribunal de Justiça de Agravo de Recurso Especial, $n^{\circ} 336.443$ AM (2013/0159660-3), Relator Ministro Antonio Saldanha Palheiro, data de publicação 02/12/2019, é estabelecido que o réu cometeu o crime de estelionato por alugar o veículo da locadora, induzindo-a em erro, utilizando a fraude. Ademais, foi praticado juntamente o crime de falsificação de documento público em relação ao documento de identidade, o que direciona de forma mais veemente o dolo do autor. 
É possível ratificar com o Superior Tribunal de Justiça. Habeas Corpus nº 468.182 -

ES, estabelece que é realmente um crime conhecido, tanto que já está apelidado como "golpe da locadora”.

Trata-se de habeas corpus substitutivo de recurso ordinário, com pedido liminar, impetrado em benefício de FABIO FERREIRA, contra v. acórdão proferido pelo eg. Tribunal de Justiça do Estado do Espírito Santo. Depreende-se dos autos que o paciente foi preso preventivamente pela prática, em tese, do delito tipificado no artigo 171, caput, e art. 288, ambos do Código Penal (estelionato e organização criminosa) e, consoante denúncia, "verifica-se tratar de "golpe da locadora", onde os carros são locados em outros Estados da Federação por pessoas portando documentos falsos, e quando esgota o prazo para devolução dos veículos alugados nas revendas, os veículos não são devolvidos, sendo quando as locadoras tentam cobrar as diárias vencidas e adotam medidas cíveis para tentar localizar e reaver seus veículos. Nesse ínterim, os criminosos vendem os veículos em outro Estado da Federação, através de documentos falsos" (fls. 1314-1315, da denúncia). (Habeas Corpus n 468.182 - ES (2018/0232018-4). Relator: Ministro Felix Fischer. Data de Julgamento: 08 de novembro de 2018. Data de publicação 13/11/2018.) (Superior Tribunal de Justiça, 2018). (grifo nosso).

Em Habeas Corpus n³90.575 - MS, Superior Tribunal de Justiça é possível verificar que transportar carros para sua posterior venda, sendo eles alugados, se caracteriza como estelionato. Este caso representa diversos outros cujo modus operandi é estabelecido de forma linear para fraudar outros.

\begin{abstract}
Vistos, Trata-se de comunicação da prisão em flagrante [...] pela prática dos crimes de estelionato, receptação e associação criminosa, respectivamente tipificados nos artigos 171, 180 e 288, todos do Código Penal. Consta do auto de prisão em flagrante que, no dia 22 de outubro de 2016, por volta das 15 horas, policiais militares faziam patrulhamento na Vila Limeira, cidade de Amambaí-MS, quando avistaram três veículos suspeitos, dois com placas de Santa Catarina e um com placas do Paraná, em um posto de combustível. Os policiais fizeram retorno para abordar os condutores dos veículos, quando então estes empreenderam fuga em alta velocidade. [...] Tais pessoas afirmaram que foram contratados por uma pessoa de alcunha "Pitbul" para transportar os veículos Siena e Corolla até o Paraguai, pelo que receberiam entre cinco a dez mil reais. O veículo Toyota Corolla, conduzido por Tiago de Assis Osório, foi encontrado na estrada que liga Amambai a Coronel Sapucaia-MS. Tiago confessou que receberia uma quantia em dinheiro para levar o veículo até o Paraguai. Os policiais constaram que o veículo Corolla estava com placas clonadas e tinha registro de roubo/furto. Os outros dois veículos envolvidos eram alugados. O Ministério Público requereu a conversão da prisão em flagrante em prisão preventiva. (Habeas Corpus N³90.575 - MS 2017/0045002-6. Relator: Ministro Nefi Cordeiro. Data:03/05/2017. Data de Publicação08/05/2017). (Grifo nosso)
\end{abstract}

Através da análise do Habeas Corpus n³65.983 - AC, Superior Tribunal de Justiça, estando essa em consonância com a anterior, observe: 
Nos termos do artigo 310 do CPP, com a nova redação dada pela Lei n. 12.403/2011, deve o juiz, ao receber o auto de prisão em flagrante, relaxar a prisão ilegal (inciso I), converter a prisão em preventiva (inciso II) ou conceder liberdade provisória com ou sem fiança (inciso III e parágrafo único).

Trata-se da imputação de crime de estelionato e associação criminosa (artigos $171 \mathrm{e}$ 288 do CP), em concurso, praticado em estado da Federação diverso do domicílio dos flagranteados, em local que não têm qualquer referência aos mesmos (Acrelândia), utilizando-se de um carro alugado, vindo de Porto Velho, e com destino final São Paulo. Os fatos se deram em comunhão de desígnio e ações entre três agentes, o que ensejou a presença do delito de associação criminosa tipificado no artigo 288 do Código Penal. Os flagranteados são naturais do Estado de São Paulo. Conforma relatado em sede policial, se deslocaram de São Paulo/SP para Porto Velho/RO e, após alugar um veículo, se deslocaram para a cidade de Rio Braco/AC e posteriormente para a comarca de Acrelândia/AC onde cometeram o delito. (Habeas Corpus n³65.983 - AC (2016/0207725-7). Relator: Ministro Nefi Cordeiro. Data: 19 de setembro de 2016. Data de publicação: 22/09/2016). (Grifo nosso).

É possível constatar que neste caso concreto do Superior Tribunal de Justiça. Habeas Corpus $n^{\circ} 239.470$ - SP, o crime estabelecido é o de estelionato, pois houve dolo prévio para a obtenção do bem.

[...] Consta dos autos que o paciente foi condenado como incurso no art. 171, caput, c.c art. 29, ambos do Código Penal, à pena de 3 (três) anos de reclusão, em regime inicial semiaberto. Extraio, do decisum, o seguinte excerto:

Ressuma dos autos, portanto, a existência de um crime de estelionato. Os dois acusados dirigiram-se até a locadora com o intuito de se apoderarem do veículo da vítima e, para tanto, ludibriaram o ofendido, inclusive valendo-se de documento e identidade falsos para a negociação.

Como bem ressaltado pelo Promotor de Justiça, inegável que os acusados agiram com dolo prévio, é dizer, firmaram o contrato já imbuídos da intenção de ingressarem na posse do veículo, posteriormente utilizado para o tráfico de entorpecentes. Note-se que não restituíram o veículo na data aprazada nem tampouco pagaram as diárias devidas, causando graves prejuízos à vítima.

Diante de tamanhos elementos de convicção, a demonstrar o dolo e má-fé com que se valeram os acusados, não há que se sustentar a atipicidade de suas condutas. (Habeas Corpus n²39.470 - SP (2012/0076785-4). Relatora: Ministra Maria Thereza De Assis Moura. Data: 20 de abril de 2012. Data de publicação: 24/04/2012). (Grifo nosso)

Como se pode averiguar na ementa abaixo, a venda de carros alugados é uma prática criminosa comum, sendo considerado apropriação indébita, somada ao caso concreto com a associação criminosa. Observe o julgado da Tribunal de Justiça do Mato Grosso do Sul no HC: 14021453920208120000 .

E M E N T A - HABEAS CORPUS - APROPRIAÇÃO INDÉBITA E ASSOCIAÇÃO CRIMINOSA - TRANCAMENTO DA AÇÃO PENAL - NÃO ACOLHIDO - PRESSUPOSTOS E CONDIÇÕES DA AÇÃO PRESENTES MATERIALIDADE E INDÍCIOS DE AUTORIA EVIDENCIADOS ATIPICIDADE DA CONDUTA NÃO VERIFICADA - ORDEM DENEGADA.

Segundo apurado, anteriormente às prisões que deram ensejo aos presentes autos, os denunciados Ariel Ferreira, Emerson Diamantino e Samanta (companheira de Ariel), 
decidiram vender na Bolívia, por U\$4.000,00 (quatro mil dólares), o veículo TCross que a denunciada Samanta havia alugado, convidando, ainda, o denunciado Emerson Rodrigues para conduzir o referido veículo até o país vizinho. Assim, os denunciados Ariel Ferreira e Emerson Diamantino iniciaram a viagem com destino à Bolívia com o veículo Ônix, com o qual posteriormente iriam voltar para Campo Grande/MS e o denunciado Emerson Rodrigues com o veículo T-Cross locado pela denunciada Samanta. Contudo, o denunciado Emerson Rodrigues foi abordado no pedágio do ponto do Rio Paraguai, na BR 262, enquanto conduzia o veículo T-Cross em direção à Corumbá/MS e, após averiguação, os policias militares levantaram que o veículo era de propriedade da empresa Unidas, estava locado em nome da denunciada Samanta e deveria ter sido restituído à proprietária no dia 20 de janeiro de 2020. Posteriormente, no mesmo local, porém no sentido Corumbá-Campo Grande foi abordado foi abordado o veículo Ônix, ondem estavam os denunciados Ariel Ferreira e Emerson Diamantino , os quais afirmaram que estavam voltando de Corumbá, pois estavam aguardando o denunciado Emerson Rodrigues , que tinha chegado, para venderem o veículo T-Cross. (Apelação. TJ-MS - HC:140214539.2020.8.12.0000, Relator: Des ${ }^{a}$. Dileta Terezinha Souza Thomaz, Data de Julgamento: 03/04/2020, $3^{\text {a }}$ Câmara Criminal, Data de Publicação: 07/04/2020). (Grifo nosso)

O Tribunal de Justiça do Distrito Federal, número 0000248-10.2018.8.07.0019, caracteriza o contrato de aluguel em que não há a intenção de efetuar seu pagamento como estelionato. Algo que está associado à prática de alugar carros para vendê-los.

PENAL E PROCESSO PENAL. APELAÇÃO CRIMINAL. ESTELIONATO. DOSIMETRIA. ANÁLISE NEGATIVA DA CONDUTA SOCIAL AFASTADA. FUNDAMENTAÇÃO INIDÔNEA. AVALIAÇÃO NEGATIVA DAS CONSEQUENNCIAS DO CRIME MANTIDA. COMPROVAÇÃO DO PREJUÍZO EXARCEBADO À VÍTIMA. DECLARAÇÕES DA VÍTIMA. SUFICIÊNCIA PROBATÓRIA. RECURSO PARCIALMENTE PROVIDO. 1. Afasta-se a valoração negativa da conduta social, pois as condutas atribuídas ao réu, seja a celebração de contrato de aluguel sem a intenção de efetuar o pagamento ou o abastecimento de veículos em postos de combustíveis com a mesma intenção, configuram, em tese, o delito de estelionato. Contudo, ainda que o réu esteja respondendo criminalmente por esses fatos, é vedada a utilização de inquéritos policiais e ações penais em curso para agravar a pena-base (Súmula 444 do STJ). (TJ-DF: 0000248-10.2018.8.07.0019, Relator: Demetrius Gomes Cavalcanti, Data de Julgamento: 16/04/2020, $3^{a}$ Turma Criminal, Data de Publicação: Publicado no PJe: 26/04/2020). (Grifo nosso)

Em análise da decisão do Tribunal de Justiça de Pernambuco apelação 003216334.2010.8.17.0810. No caso concreto o ato da ré não se caracterizou como apropriação indébita, pois não tinha animus domini e sim tinha intenção obter vantagem ilícita em relação à locadora e aos participantes do consórcio. Dessa forma, sua única intenção era enganar e receber vantagem sobre os objetos. Fato não caracterizado na apropriação indébita.

PENAL E PROCESSO PENAL. APROPRIAÇÃO INDÉBITA. ESTELIONATO. CONCURSO MATERIAL. CRIME CONTINUADO. PRELIMINAR DE NULIDADE. CERCEAMENTO DE DEFESA PELO INDEFERIMENTO DE PEDIDO DE ACAREAÇÃO. DECISÃO JUSTIFICADA PELO JUIZ. AUSÊNCIA 
DE PREJUÍZO. PRINCÍPIO PAS DE NULLITÉ SANS GRIEF. PRELIMINAR REJEITADA. NÃO OCORRÊNCIA DO DELITO DE APROPRIAÇÃO INDÉBITA. DOLO NÃO COMPROVADO. ESTELIONATO. SENTENÇA QUE CONDENOU A FATO DIVERSO DO PREVISTO NA DENÚNCIA E DO QUAL RECORRENTE SE DEFENDIA. NULIDADE DA SENTENÇA QUANTO AO DELITO DE ESTELIONATO. APELO PARCIALMENTE PROVIDO PARA ABSOLVER A RECORRENTE DO DELITO DE APROPRIAÇÃO INDÉBITA E, DE OFÍCIO, ANULAR A SENTENÇA NO TOCANTE AO DELITO DE ESTELIONATO. DECISÃO UNÂNIME. A conduta da apelante consistiu em entregar aos clientes, que haviam contratado o consórcio, carros provisórios a serem utilizados enquanto o veículo objeto do consórcio não lhes era entregue. Apesar do atraso na devolução dos carros de propriedade das locadoras, não restou bem demonstrado nos autos o dolo da acusada em se apropriar dos veículos como se fossem seus. Não há dúvidas de que houve descumprimento do contrato de locação pela acusada, todavia tal fato não é apto, por si só, para caracterizar o delito de apropriação indébita. Ademais, o atraso na devolução dos bens pode ser resolvido na esfera cível. III - No caso concreto é possível aferir o dolo da recorrente em obter vantagem ilícita (receber os carros sem dar o pagamento em contrapartida), em face da locadora de veículos, mantendo-a em erro (acreditava que receberia remuneração pelo aluguel dos carros) através de artifício, (entrega de cheques pós-datados, alguns que foram sustados e outros emitidos sem provisão de fundos). (TJ-PE - APL: 3591817; 003216334.2010.8.17.0810. PE, Relator: Alexandre Guedes Alcoforado Assunção, Data de Julgamento: 18/12/2018, 4 a Câmara Criminal, Data de Publicação: 01/07/2019). (Grifo nosso)

Quando há contrato previamente firmado, segundo o Tribunal de Justiça do Mato Grosso, AC: 0002388-10.2016.8.11.0008, não há furto qualificado, porque o bem não foi subtraído mediante vigilância, e sim apropriação indébita. Sanando, dessa forma, tal possível divergência.

\begin{abstract}
APELAÇÃO CÍVEL - AÇÃO DE COBRANÇA C/C OBRIGAÇÃO DE FAZER E PERDAS E DANOS - SEGURO DE VEÍCULO - LOCADORA DE AUTOMÓVEL - APROPRIAÇÃO INDÉBITA - NEGATIVA DE PAGAMENTO DO PRÊMIO - CLÁUSULA DE EXCLUSÃO - INDENIZAÇÃO INDEVIDA RECURSO DESPROVIDO - SENTENÇA MANTIDA. O contrato de seguro exclui a indenização para o caso de perda do veículo decorrente de apropriação indébita. Não há como admitir a ocorrência de furto qualificado para o caso em apreço, haja vista que o veículo foi retirado da loja mediante contrato de locação, portanto, não houve subtração do bem.(TJ-MT - AC: 00023881020168110008 MT, Relator: Antonia Siqueira Goncalves, Data de Julgamento: 05/06/2019, Data de Publicação: 15/08/2019). (Grifo nosso).
\end{abstract}

Veja-se que no estelionato há ardil para que a vítima entregue seu bem voluntariamente, enquanto no furto qualificado pela fraude o ardil é para impedir a atenção da vítima, para dessa forma ser subtraído.

O julgado do Tribunal de Justiça do Distrito Federal de número 20180710042860 esclarece a diferenciação do crime de estelionato e apropriação indébita em relação ao momento do dolo, sendo nesse caso anterior ao meio fraudulento. Analise: 
Estelionato. Dolo anterior. Emprego do meio fraudulento. Coautoria. Ressarcimento posterior. Continuidade delitiva. 1 - O estelionato pressupõe vontade deliberada de, mediante ardil ou fraude, induzir a vítima em erro e obter vantagem ilícita em detrimento alheio. O dolo deve ser anterior ao emprego do meio fraudulento. Se o dolo do agente é preordenado, não há simples inadimplemento contratual. 2 - Comete o crime de estelionato aquele que, mediante ardil, induz a vítima em erro - oferecendo serviço e produto que não pretende entregar -, realiza transação no cartão de crédito da vítima, em valor superior ao ajustado, obtendo vantagem ilícita, em prejuízo dessa. [...] 4 - O estelionato é crime material que se consuma com a obtenção de vantagem econômica ilícita e ocorrência de prejuízo alheio. Eventual ressarcimento posterior não exime os réus da responsabilidade penal. 5 - Crimes, embora da mesma espécie - estelionato - e modos de execução parecidos, mas praticados sem unidade de desígnios, em datas e locais diversos, não se qualificam como continuados. Denotam reiteração ou habitualidade criminosa, que impede seja reconhecido o benefício do art. 71 do CP. 6 - Apelação do MP provida. Não provida a dos réus. (TJ-DF 0004042-75.2018.8.07.0007, Relator: JAIR SOARES, Data de Julgamento: 10/10/2019, Data de Publicação: Publicado no DJE: 15/10/2019.) (Grifo nosso).

Já no caso decidido pelo Tribunal de Justiça de São Paulo houve apropriação indébita, pois a priori houve licitude no aluguel e utilização do bem. No entanto, a posteriori o réu não quis devolver o objeto, ocorrendo a apropriação indébita do bem. Dessa forma foi necessária a intervenção da Polícia Militar para a recuperação de tal objeto.

\footnotetext{
Apelação do Ministério Público - Apropriação indébita - Absolvição sumária dos acusados - Reforma que se impõe - Retenção de veículo alugado, que, mesmo após reiteradas cobranças (não respondidas), só foi restituído à locadora mediante a intervenção da Polícia Militar, que o localizou estacionado na via pública - Conduta suficiente para, "ab initio", tornar plausível a prática do delito do art. 168 do CP Precedentes desta Corte - Decisão prematura, em havendo a possibilidade de mais bem apurar-se o elemento subjetivo, no curso da instrução processual Prosseguimento do feito - Recurso provido. (TJ-SP 0093604-11.2013.8.26.0050, Relator: Ivan Sartori, Data de Julgamento: 14/12/2017, $12^{\mathrm{a}}$ Câmara Criminal Extraordinária, Data de Publicação: 15/12/2017).
}

Como no exemplo citado, há a discricionariedade seja do promotor ou do juiz para a efetivação e classificação do crime. Porque pode ter ocorrido um contrato lícito, no entanto há o dolo de executar, independente houve licitude em algum momento ou não.

Com tais julgados analisados é possível concluir que no furto mediante fraude é preciso a vigilância da vítima o que na maioria dos casos de “fraudes da locadora” o bem, após contrato, é alugado sem vigilância. Desse modo, tal crime é direcionado de forma menos duvidosa ao caso concreto.

Já nos casos de estelionato e apropriação indébita, os tribunais ainda não alinharam sobre qual crime é o melhor direcionado ao caso concreto, como pôde observar, em alguns casos há fraude para a entrega da coisa, como por exemplo, uso de documentos falsos, mesmo 
assim caracterizou-se o crime em apropriação indébita, o qual, supostamente, se estabelece pela intenção posterior de ter o objeto para si e não de fraudar para ter a entrega dele.

\section{CONSIDERAÇõES FINAIS}

Segundo o narrado, tal temática é essencial para a diferenciação de tais crimes, tanto para o Ministério Público na hora de produzir a denúncia, quanto para os advogados e os juízes.

Percebe-se que cada tipo de especificação do crime tem tênues diferenças em certos quesitos. Assim, os delitos nos casos do golpe da locadora se diferenciam na versão do estelionato, da apropriação indébita e do furto mediante fraude.

O estelionato utiliza da fraude para obter para si, ou para outrem vantagem ilícita, geralmente mantendo ou induzindo a vítima em erro, com uma falsa percepção de realidade, com a vontade $a b$ initio, ou seja, intenção de ludibriar a vítima desde o início. Em relação ao caso em tela, pode-se demonstrar o exemplo do golpe da locadora utilizando um documento falsificado, induzindo a vítima (o representante da locadora) em erro para que ela entregue o bem.

Na apropriação indébita, o agente abusa da condição de possuidor ou detentor de algum bem móvel para dele, desse modo, apropriar-se. Sua consumação ocorre com a inversão da posse do objeto, por exemplo com a venda do bem, através da simulação de ser o dono. Nesse conceito há o animus domini, ou seja, ânimo de ser dono do objeto. Seu início decorre da posse lícita, sem fraude desde o princípio.

No furto mediante fraude, em relação ao golpe da locadora, em decorrência da pessoa ter a posse do bem, dificilmente ela é vigiada, o que descaracteriza a prática para esse delito, sendo, dessa forma, solucionado como apropriação indébita ou estelionato.

A principal lacuna presente dentro da temática é que, como ocorreu no delito do test drive de veículos automotores os interesses da política criminal podem consolidar o entendimento em determinado direcionamento que seja mais interessante. Nesse caso, o crime consiste em estelionato, mas foi consolidado como furto mediante fraude para, principalmente, a reparação do dano pelo seguro.

Ademais, como ocorreu no projeto de lei n. 2.725/2019, no qual, em decorrência do modus operandi o delito foi amoldado à apropriação indébita e ao estelionato, abarcando de forma mais abrangente os delitos. 
Segundo o exposto, portanto, é necessária a observação minuciosa da prática criminosa para o esclarecimento de qual tipo penal é mais direcionado. Os crimes que mais se encaixam para a prática citada, por exemplo - Em casos que um cliente aluga um carro de locadoras de veículos, para, a princípio, fazer uma viagem e logo após tal veículo é dado como roubado, sendo comunicado tanto a locadora quanto a autoridade policial. No entanto, não há provas firmes de que houve realmente o roubo - é o crime de estelionato, pois há o dolo de obter, para si vantagem ilícita, consistente em vender o carro, geralmente na fronteira, recebendo o valor monetário consistente dessa prática.

\section{REFERÊNCIAS BIBLIOGRÁFICAS}

BRASIL. Código Civil Brasileiro. Lei n 10.406, de janeiro de 2002. Disponível em: http://www.planalto.gov.br/ccivil_03/leis/2002/L10406compilada.htm. Acesso em: 15 de julho de 2020.

BRASIL. Código Penal Brasileiro. Lei n 2.848, de 7 de dezembro de 1940. Disponível em: http://www.planalto.gov.br/ccivil_03/decreto-lei/del2848compilado.htm. Acesso em: 15 de julho de 2020.

BRASIL. Superior Tribunal de Justiça. Agravo em Recurso Especial n 336.443 - AM (2013/0159660-3). Relator: Ministro Antonio Saldanha Palheiro. Data de publicação 02/12/2019. Acesso em: 3 de setembro de 2020.

BRASIL. Superior Tribunal de Justiça. Conflito de Competência n ${ }^{163.464-D F}$ (2019/0025129-3). Suscitante: Juízo de Direito da $3^{a}$ Vara Criminal de Taguatinga-DF. Relator: Ministro Nefi Cordeiro. Data de publicação 18/09/2019. Acesso em: 4 de setembro de 2020.

BRASIL. Superior Tribunal de Justiça. Habeas Corpus n²39.470 - SP (2012/0076785-4). Relatora: Ministra Maria Thereza De Assis Moura. Data: 20 de abril de 2012. Data de publicação: 24/04/2012. Acesso em: 10 de julho de 2020.

BRASIL. Superior Tribunal de Justiça. Habeas Corpus n³65.983 - AC (2016/0207725-7). Relator: Ministro Nefi Cordeiro. Data: 19 de setembro de 2016. Data de publicação: 22/09/2016. Acesso em: 15 de julho de 2020

BRASIL. Superior Tribunal de Justiça. Habeas Corpus n³90.575 - MS (2017/0045002-6). Relator: Ministro Nefi Cordeiro. Data:03 de maio de 2017. Data de publicação: 08/05/2017. Acesso em: 13 de julho de 2020.

BRASIL. Superior Tribunal de Justiça. Habeas Corpus n 468.182 - ES (2018/0232018-4). Relator: Ministro Felix Fischer. Data de Julgamento: 08 de novembro de 2018. Data de publicação 13/11/2018. Acesso em: 17 de julho de 2020. 
BRASIL. Superior Tribunal de Justiça. Habeas Corpus n 548.435- SE (2019/0356241-1). Relator: Ministro Reinaldo Soares da Fonseca. Data de Julgamento: 29/09/2019. Data de Publicação: 02/12/2019. Acesso em 18 de julho de 2020.

BRASIL. Superior Tribunal de Justiça. Habeas Corpus nº 560.437-SE (2020/0028313-0). Relator: Ministro Jorge Mussi. Data de publicação 13/02/2020. Acesso em: 20 de julho de 2020.

BRASIL. Tribunal de Justiça de Distrito Federal. TJ-DF 0000248-10.2018.8.07.0019, Relator: Demetrius Gomes Cavalcanti, Data de Julgamento: 16/04/2020, $3^{\text {a }}$ Turma Criminal, Data de Publicação: Publicado no PJe: 26/04/2020. Acesso em: 27 de julho de 2020

BRASIL. Tribunal de Justiça do Distrito Federal. TJ-DF 0004042-75.2018.8.07.0007, Relator: Jair Soares, Data de Julgamento: 10/10/2019, $2^{\mathrm{a}}$ Turma Criminal, Data de Publicação: Publicado no DJE: 15/10/2019. Acesso em: 18 de julho de 2020.

BRASIL. Tribunal de Justiça do Mato Grosso. Apelação. TJ-MT - AC: 00023881020168110008 MT, Relatora: Antonia Siqueira Goncalves, Data de Julgamento: 05/06/2019, Vice-Presidência, Data de Publicação: 15/08/2019. Acesso em: 10 de agosto de 2020.

BRASIL. Tribunal de Justiça do Mato Grosso do Sul. Apelação. TJ-MS - HC: 140214539.2020.8.12.0000, Relator: Desa . Dileta Terezinha Souza Thomaz, Data de Julgamento:

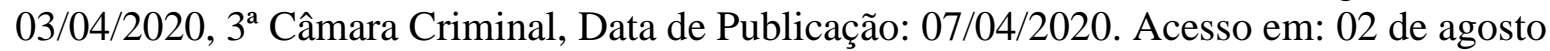
de 2020 .

BRASIL. Tribunal de Justiça do Paraná. TJ-PR - AC: 2141351 PR Apelação Cível 0214135-1, Relator: Prestes Mattar, Data de Julgamento: 12/11/2002, Sétima Câmara Cível (extinto TA), Data de Publicação: 06/12/2002. Acesso em: 02 de agosto de 2020.

BRASIL. Tribunal de Justiça de Pernambuco. TJ-PE - APL: 3591817 PE 003216334.2010.8.17.0810, Relator: Alexandre Guedes Alcoforado Assunção, Data de Julgamento: 18/12/2018, $4^{\text {a }}$ Câmara Criminal, Data de Publicação: 01/07/2019. Acesso em: 26 de julho de 2020.

BRASIL. Tribunal de Justiça de São Paulo. TJ-SP 0093604-11.2013.8.26.0050, Relator: Ivan Sartori, Data de Julgamento: 14/12/2017, $12^{\text {a }}$ Câmara Criminal Extraordinária, Data de Publicação: 15/12/2017. Acesso em: 08 de setembro de 2020.

CUNHA, Rogério Sanches. Manual de Direito Penal: Parte Especial. Volume Único. $9^{\circ}$ Edição. Editora Juspodivn, 2017.

MASSON, Cleber. Código Penal Comentado 2. Ed. Ver., atual. e ampl. Rio de Janeiro: Forense; São Paulo: Método, 2014.

NUCCI, Guilherme de Souza. Manual de direito penal. 16 ed. Rio de Janeiro: Forensse, 2020.

NUNES, Rosana. PRF apreende em 24h, segundo carro locado em outro Estado que seguia para a Bolívia. Jornal Diário Corumbaense. Publicado em: 26/01/2019. Disponível em https://diarionline.com.br/?s=noticia\&id=107774. Acesso 06 de julho de 2020. 
RIO DE JANEIRO. Assembleia Legislativa. Projeto de Lei Complementar PL 2735. 2019. Altera o Decreto-lei n ${ }^{\circ}$ 2.848, de 1940. Código Penal. Disponível em:

https://www.camara.leg.br/proposicoesWeb/fichadetramitacao?idProposicao=2200710.Acess o em: 13 de julho de 2020.

ROCKENBACH, Pedro. Criminosos aplicam golpes contra locadoras de veículos e furtam carros em Santa Catarina. G1, Globo, Santa Catarina. Publicada em: 06/06/2019.

Disponível em:https://g1.globo.com/sc/santa-catarina/noticia/2019/05/06/criminosos-aplicamgolpes-contra-locadoras-de-veiculos-e-furtam-carros-em-sc.ghtml. Acesso em: 25 de junho de 2020.

SOUZA, Artur de Brito Gueiros; Japiassú, Carlos Eduardo Adriano. Direito penal: volume único. São Paulo: Atlas, 2018.

Data de submissão: 19/10/2020

Data de aprovação: 03/11/2020

Data de publicação: 31/12/2020

Este trabalho está licenciado sob uma licença Creative Commons Attribution 4.0 International License. 